\title{
EFFECT OF DISEASE ACTIVITY AND FUNCTIONAL IMPAIRMENT IN PATIENTS WITH RHEUMATOID ARTHRITIS ON SATISFACTION WITH PROVIDED RHEUMATOLOGY HEALTH CARE
}

\author{
UTJECAJ AKTIVNOSTI BOLESTI I FUNKCIONALNE \\ ONESPOSOBLJENOSTI BOLESNIKA S REUMATOIDNIM ARTRITISOM \\ NA RAZINU ZADOVOLJSTVA PRUŽENOM REUMATOLOŠKOM USLUGOM
}

\author{
Darija Čubelić1 ${ }^{1}$ Mirna Reihl Crnogaj ${ }^{2}$, Miroslav Mayer ${ }^{1}$ \\ ${ }^{1}$ Division of Clinical Immunology and Rheumatology, Department of Internal Medicine, \\ School of Medicine, University Hospital Center Zagreb, Croatia \\ / Zavod za kliničku imunologiju i reumatologiju, Klinika za unutarnje bolesti Medicinskog fakulteta Sveučilišta u Zagrebu, \\ Klinički bolnički centar Zagreb \\ ${ }^{2}$ Department of Physical Medicine, Rehabilitation, and Rheumatology, \\ National Memorial Hospital Vukovar, Vukovar, Croatia \\ / Odsjek za fizikalnu medicinu, rehabilitaciju i reumatologiju, \\ Nacionalna memorijalna bolnica Vukovar, Vukovar, Hrvatska
}

Corresponding author / Adresa autora za dopisivanje:

Darija Čubelić, MD

Division of Clinical Immunology and Rheumatology / Zavod za kliničku imunologiju i reumatologiju

Department of Internal Medicine / Klinika za unutarnje bolesti

University of Zagreb, School of Medicine / Medicinski fakultet Sveučilišta u Zagrebu

University Hospital Center Zagreb / Klinički bolnički centar Zagreb

Kišpatićeva 12

10000 Zagreb

Croatia / Hrvatska

Tel. +385994092808

E-mail: darija_cubelic@yahoo.com

Received / Primljeno: March 13, 2020 / 13. ožujka 2020.

Accepted / Prihvaćeno: June 15, 2020 / 15. lipnja 2020.

\section{Abstract}

Rheumatoid arthritis (RA) is a disease that requires regular monitoring of therapeutic efficacy and patients' quality of life (QOL). The aim of this study is to determine the influence of disease activity and duration, as well as functional disability, on the patients' perception of satisfaction with the provided care, and to evaluate the satisfaction with respect to the patient-physician relationship and the factors that affect the patients' satisfaction level.

The observational non-interventional study included 53 consecutive RA patients who regularly attend the outpatient clinic. Prior to the scheduled examination the patients completed a standardized Patient Satisfaction Questionnaire and a Health Care Assessment Questionnaire (HAQ). The patients were divided according to their HAQ score, disease activity measured by DAS28 score (Disease Activity Score 28), disease duration, and presence of bDMARDs (biologic disease-modifying antirheumatic drugs) in therapy.

The results showed that the patients were largely satisfied with the service provided. The highest scores were achieved in the categories of the technical quality and competence of the physician and the doctor's attitude towards the patient. The lowest scores were related to the inability of an easy telephone access or emergency consultation and to the time spent in the waiting room. The level of disease activity did not significantly affect the degree of satisfaction with the provided health care. Additionally, patients who were classified as having severe to very severe disability by HAQ score had slightly lower satisfaction rates in all examined categories. Furthermore, patients treated with bDMARDs and those with disease lasting more than five years reported higher satisfaction rates in all categories.

In conclusion, patients with a higher degree of disability experience a slightly lower level of satisfaction with medical care, whereas patients with long-standing disease and those treated with bDMARDs report higher levels of 
satisfaction with the specialist care. Satisfaction with the professional service provided in the specialist rheumatology unit can contribute to the improvement of the patients' perception of satisfaction with QOL.

KeYwords: Arthritis, rheumatoid - drug therapy, psychology; Biological products - therapeutic use; Severity of illness index; Patient satisfaction; Physician-patient relation; Patient reported outcome measures; Rheumatology; Surveys and questionnaires

\section{SAŽETAK}

Reumatoidni artritis (RA) bolest je koja nalaže kontinuirano praćenje učinkovitosti liječenja i kvalitete života bolesnika. Ciljevi istraživanja bili su utvrđivanje utjecaja aktivnosti bolesti na percepciju zadovoljstva bolesnika, evaluacija zadovoljstva bolesnika odnosom liječnik - pacijent te identifikacija čimbenika koji utječu na razinu zadovoljstva.

Ova presječna opservacijska neintervencijska studija obuhvatila je 53 konsekutivna bolesnika s RA koji su dolazili na redovite ambulantne preglede u Zavod za kliničku imunologiju i reumatologiju. Bolesnici su prije pregleda ispunili standardizirani Upitnik o zadovoljstvu pacijenata te Upitnik o procjeni općega zdravstvenog stanja (HAQ). Ispitanici su podijeljeni u skupine prema vrijednostima rezultata HAQ-a, aktivnosti bolesti i njezinu trajanju te ovisno o tome primaju li biološku terapiju.

Rezultati istraživanja pokazali su da su bolesnici uvelike zadovoljni pruženom uslugom. Najviše ocjene postignute su u kategorijama tehničke kvalitete i kompetentnosti liječnika te odnosa liječnika prema bolesniku. Najniže ocjene zadovoljstva odnosile su se na nemogućnost jednostavnoga telefonskog pristupa ili izvanredne konzultacije te na duljinu čekanja u čekaonici.

Razina aktivnosti bolesti mjerena prema DAS 28-SE (engl. Disease Activity Score 28) nije bitno utjecala na stupanj zadovoljstva bolesnika pruženom uslugom. Nadalje, bolesnici koji su prema HAQ-u ubrojeni u skupinu teške do vrlo teške onesposobljenosti javili su diskretno niži stupanj zadovoljstva u svim ispitivanim kategorijama. Također, bolesnici liječeni biološkim lijekovima i oni s trajanjem bolesti duljim od 5 godina pokazali su više razine zadovoljstva u svim kategorijama.

Zaključno, bolesnici s višom razinom funkcionalne onesposobljenosti izrazili su nešto nižu razinu zadovoljstva pruženom skrbi u reumatološkoj poliklinici, dok su bolesnici s dugotrajnom bolesti, kao i oni liječeni biološkom terapijom izrazili veće zadovoljstvo pruženom skrbi. Zadovoljstvo pacijenata specijalističkom uslugom pridonosi njihovu većem zadovoljstvu kvalitetom života.

KLJUČNE RIJEČI: Reumatoidni artritis - farmakoterapija, psihologija; Biološki lijekovi - terapijska uporaba; Ocjena težine bolesti; Zadovoljstvo bolesnika; Odnos liječnika i bolesnika; Procjene bolesnika o kvaliteti skrbi; Reumatologija; Ankete i upitnici

\section{INTRODUCTION}

Treatment of patients with rheumatoid arthritis (RA) is inconceivable without monitoring disease activity using composite indices, which are part of the current therapeutic recommendations (1). Physicians base their therapeutic decisions mainly on disease activity or measurements of treatment outcome, without taking into account parameters such as patient satisfaction or patients' attitude to the issue of changes in the therapy $(1,2)$. Composite indices - DAS28 (Disease Activity Score 28), SDAI (Simple Disease Activity Index), and mHAQ (Modified Health Assessment Questionnaire) may be affected by comorbidities such as infections or fibromyalgia, conditions that commonly occur in patients with rheumatoid arthritis $(3,4)$. Individual understading of the disease is not always related exclusively to the current disease activity, but may be influenced by various factors that are not directly related to the disease or rational factors. Whether the patient's perspective on disease activity is in line with the

\section{UVOD}

Liječenje bolesnika s reumatoidnim artritisom (RA) nezamislivo je bez praćenja aktivnosti bolesti s pomoću kompozitnih indeksa, koji su dio vrijedećih terapijskih preporuka (1). Liječnici temelje terapijske odluke uglavnom na aktivnosti bolesti odnosno mjerama ishoda liječenja, ne uzimajući u obzir parametre kao što su zadovoljstvo bolesnika ili njihovo stajalište o pitanju promjene terapije $(1,2)$. Kompozitni indeksi - DAS 28 (engl. Disease Activity Score 28), SDAI (engl. Simple Disease Activity Index) i mHAQ (engl. Modified Health Assessment Questionnaire) mogu biti pod utjecajem komorbiditeta kao što su infekcije ili fibromialgija, stanja koja se često javljaju u bolesnika s reumatoidnim artritisom $(3,4)$. Individualno poimanje bolesti ne mora biti povezano samo s trenutačnom aktivnosti bolesti, već može biti pod utjecajem raznih čimbenika koji nisu u direktnoj vezi s bolešću ili racionalnim faktorima. Pitanje je li bolesnikova perspektiva o aktivnosti bolesti u skladu s indeksima aktivnosti bo- 
disease activity indices and therapeutic recommendations is crucial for the implementation of these recommendations in everyday clinical practice (5).

Patient-reported outcome measures (PROM) in rheumatology include a global assessment of disease activity as well as a global assessment of pain, physical function, health-related quality of life (HRQoL) measurements, and the level of fatigue in patients. They are used to assess the effectiveness of RA treatment in randomized clinical trials (6), but their inclusion in clinical practice is also becoming increasingly impor$\operatorname{tant}(7,8)$.

The aim of this study was to determine the impact of disease activity on the perception of patient satisfaction, to evaluate patient satisfaction with the doctorpatient relationship, and to identify factors that affect the level of satisfaction. We asked these questions because we wanted to get an insight into the quality of care and subjective perception of the quality of care in the Division of Clinical Immunology and Rheumatology Clinic, in view of the workload of the clinic.

\section{SUBJECTS AND METHODS}

The average observational non-interventional study included 53 patients with RA who come to the Division of Clinical Immunology and Rheumatology for regular follow-up examinations. Patients completed the Patient Satisfaction Questionnaire taken from a previous UK study (Likert scale) (9) and the General Health Assessment Questionnaire (HAQ), which divided the subjects into three groups depending on the outcome (0-1: mild to moderate disability; $1-2$ : moderate to severe disability; 2-3: severe to very severe disability). The subjects had DAS28 calculated independently of the physician and were divided into two groups (<2.6: remission and > 2.6: active disease). They were also divided into two groups depending on whether they were receiving biological therapy or not. The statistical analysis, in addition to descriptive statistics, included T-test for dependent samples and ANOVA analysis. Significance was determined at the level of $\mathrm{p}<0.05$.

\section{RESULTS}

A satisfaction questionnaire was completed by 53 patients with established RA. The average age was 55.1 (24 - 72), there were 9 male (17\%) and 44 female respondents $(83 \%)$. Depending on the duration of the disease, the subjects were divided into two groups - 6 subjects with RA duration of less than 5 years, and 47 subjects with the disease diagnosed more than 5 years before. The mean value of DAS28-erythrocyte sedimentation rate (DAS28-SE) result was $3.37 \pm 1.39$, while the mean value of the HAQ index was $1.09 \pm$ lesti i terapijskim preporukama ključno je za implementaciju navedenih preporuka u svakodnevnu kliničku praksu (5).

Mjere ishoda koje navodi pacijent (engl. Patient reported outcome measures - PROM) u reumatologiji obuhvaćaju globalnu procjenu aktivnosti bolesti, kao i globalnu procjenu boli, fizičke funkcije, zatim mjere kvalitete života povezane sa zdravljem (engl. Health-Related Quality of Life - HRQoL) te razinu umora kod bolesnika. One se rabe za procjenu učinkovitosti liječenja RA u randomiziranim kliničkim studijama (6), ali i njihova inkluzija u kliničku praksu postaje sve važnija $(7,8)$.

Ciljevi ovog istraživanja bili su utvrđivanje utjecaja aktivnosti bolesti na percepciju zadovoljstva bolesnika, evaluacija zadovoljstva bolesnika odnosom liječnik pacijent te identifikacija čimbenika koji utječu na razinu zadovoljstva. Navedena pitanja postavili smo jer smo željeli dobiti uvid u kvalitetu skrbi, odnosno subjektivnu percepciju kvalitete skrbi u poliklinici Zavoda za kliničku imunologiju i reumatologiju, a s obzirom na opterećenost polikliničkog pogona.

\section{ISPITANICI I METODE}

Presječna opservacijska neintervencijska studija obuhvatila je 53-je bolesnika s RA koji dolaze na redovite ambulantne preglede u Zavod za kliničku imunologiju i reumatologiju. Bolesnici su ispunili Upitnik o zadovoljstvu pacijenata preuzet iz prijašnjeg istraživanja provedenoga u Velikoj Britaniji (Likertova ljestvica) (9) te Upitnik o procjeni općega zdravstvenog stanja (HAQ) koji je podijelio ispitanike $u$ tri skupine ovisno o rezultatu ( 0 - 1: blage do umjerene onesposobljenosti; 1 - 2: umjerena do teška onesposobljenost; 2 - 3: teška do vrlo teška onesposobljenost). Ispitanicima je izračunana vrijednost DAS 28 neovisno o ordinirajućem liječniku te su podijeljeni u dvije skupine $(<2,6-$ remisija i $>2,6$ - aktivna bolest). Podijeljeni su također u dvije skupine ovisno o tome primaju li biološku terapiju ili ne. Statistička je analiza, uz deskriptivnu statistiku, uključila T-test za zavisne uzorke i analizu ANOVA. Značajnost je utvrđena na razini $\mathrm{p}<0,05$.

\section{REZULTATI}

Upitnik o zadovoljstvu ispunilo je 53-je bolesnika s etabliranim RA. Prosjek godina bio je 55,1 (24-72), muških ispitanika bilo je 9 (17\%), a ispitanica 44 (83\%). Ovisno o trajanju bolesti, ispitanici su podijeljeni $\mathrm{u}$ dvije skupine: 6-ero ispitanika s trajanjem RA kraćim od 5 godina te 47 -ero ispitanika s bolešću dijagnosticiranom prije više od 5 godina. Srednja vrijednost rezultata DAS 28 - sedimentacija eritrocita (DAS 28-SE) iznosila je 3,37 $\pm 1,39$, dok je srednja vrijednost indeksa HAQ-a bila 1,09 $\pm 0,63$. Ukupno je 29 -ero paci- 


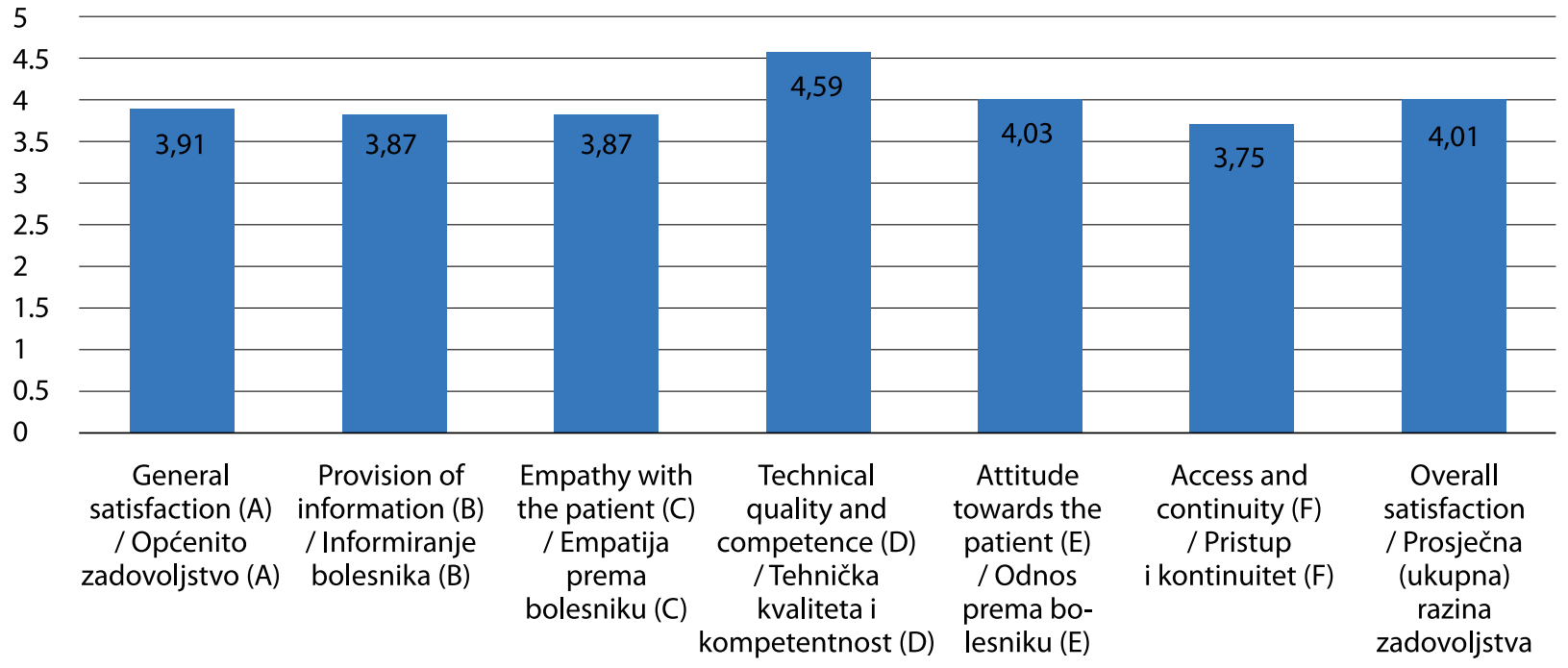

FIGURE 1. Mean satisfaction scores in the main categories of interest

SLIKA 1. Srednja vrijednost ocjene zadovoljstva u ispitivanim kategorijama

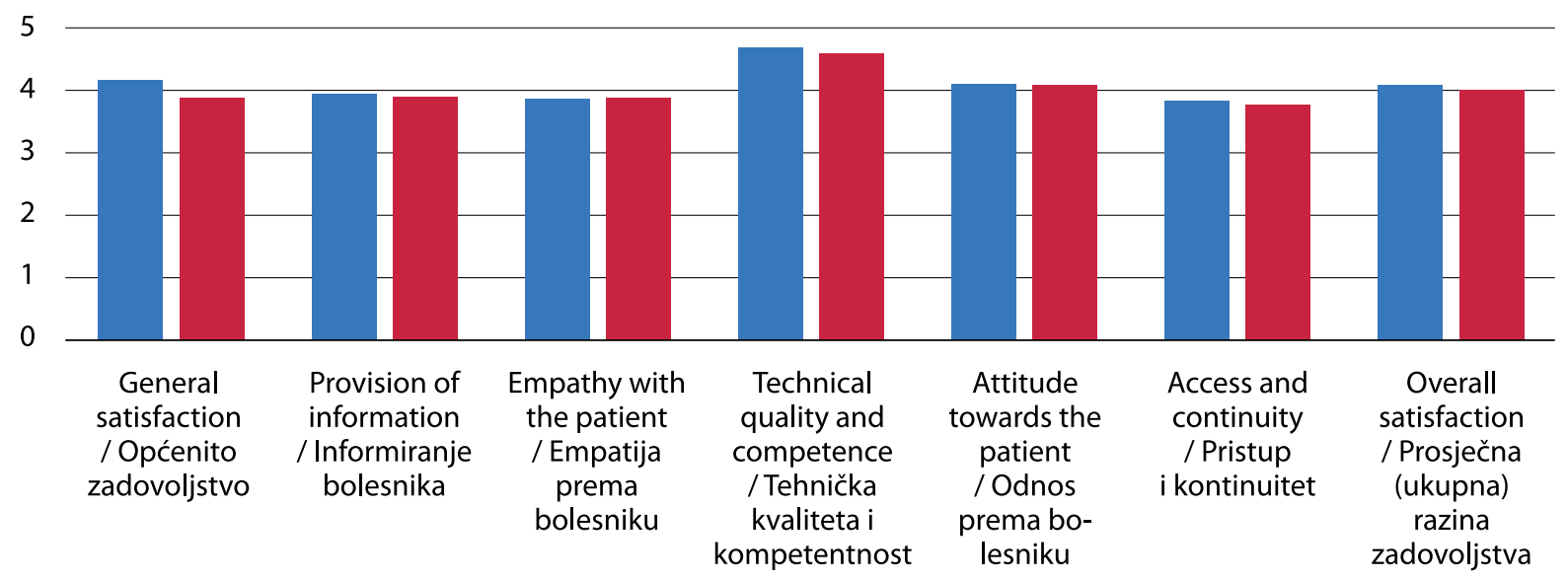

DAS $<2.6 \square$ DAS $>2.6$

FIGURE 2. Satisfaction score according to disease activity

SLIKA 2. Ocjena zadovoljstva s obzirom na aktivnost bolesti

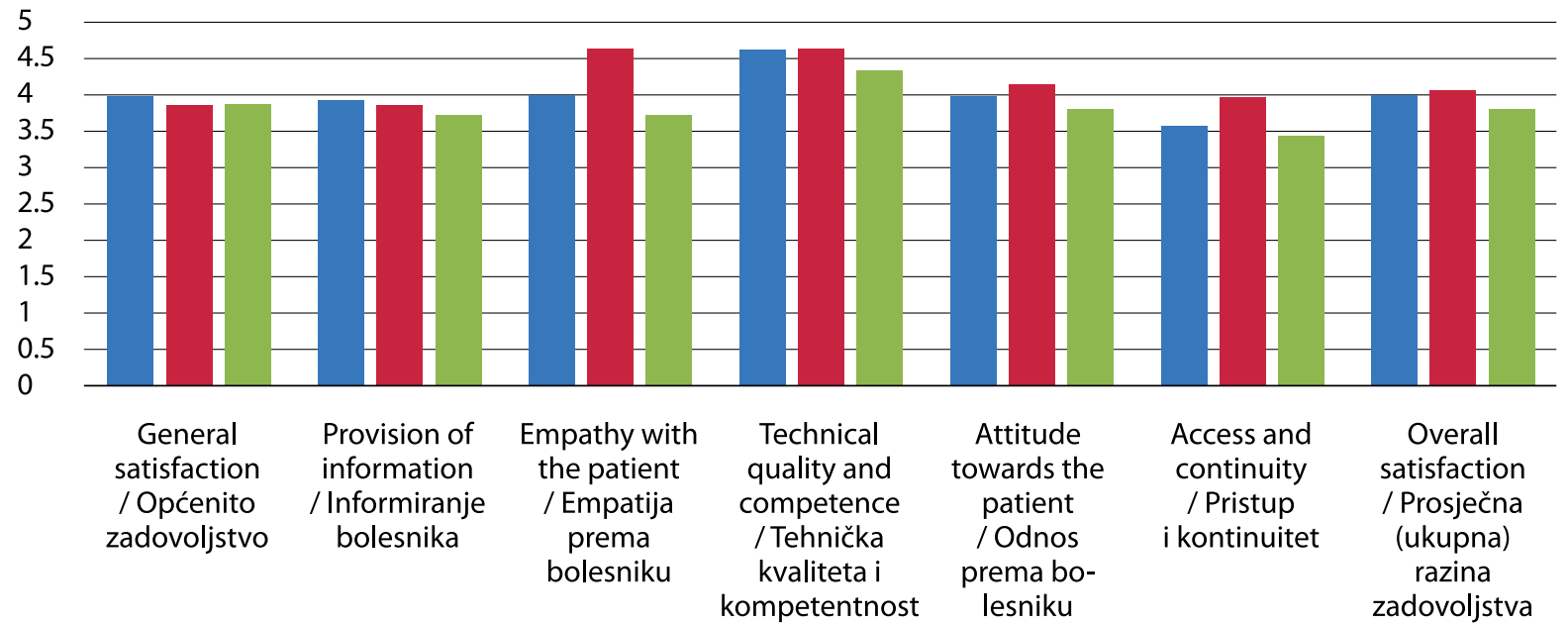

HAQ 0-1 HAQ 1-2 HAQ 2-3

FIGURE 3. Satisfaction score according to functional disability groups SLIKA 3. Ocjena zadovoljstva prema kategorijama funkcionalne onesposobljenosti 


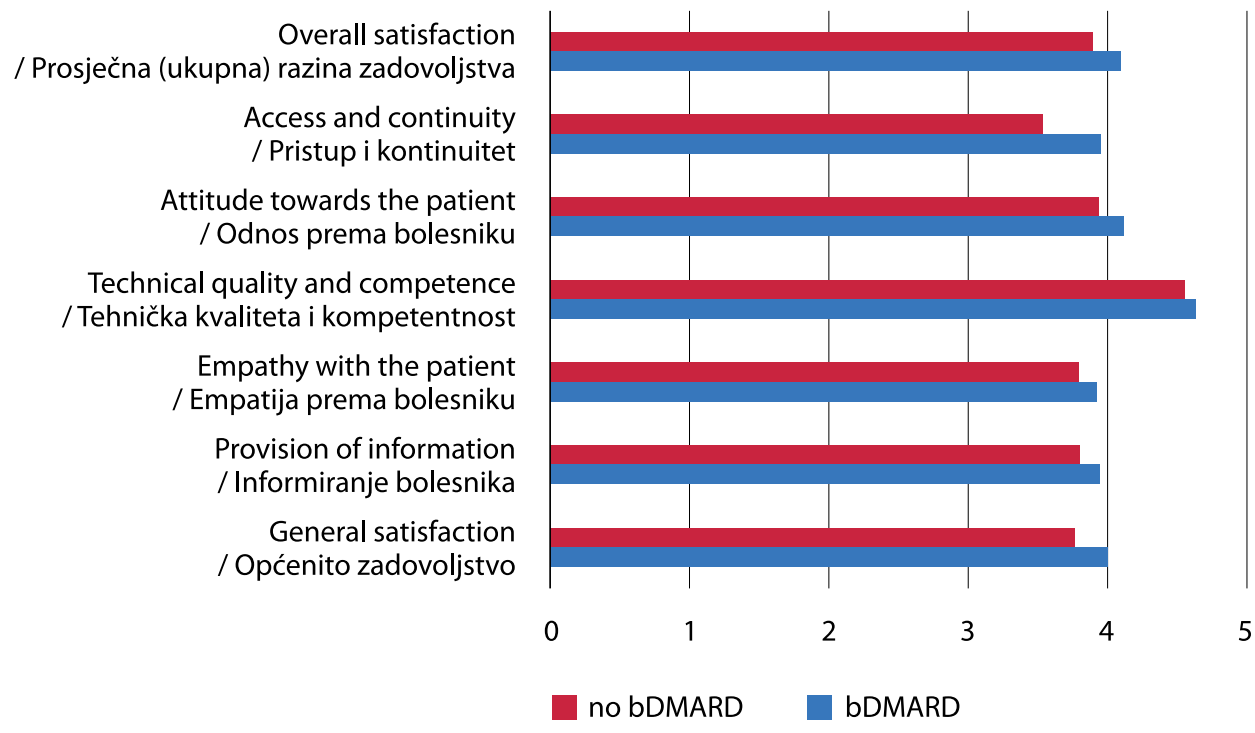

Overall satisfaction / Prosječna (ukupna) razina zadovoljstva

Access and continuity / Pristup i kontinuitet

Attitude towards the patient / Odnos prema bolesniku

Technical quality and competence / Tehnička kvaliteta i kompetentnost

Empathy with the patient / Empatija prema bolesniku

Provision of information / Informiranje bolesnika

General satisfaction / Općenito zadovoljstvo

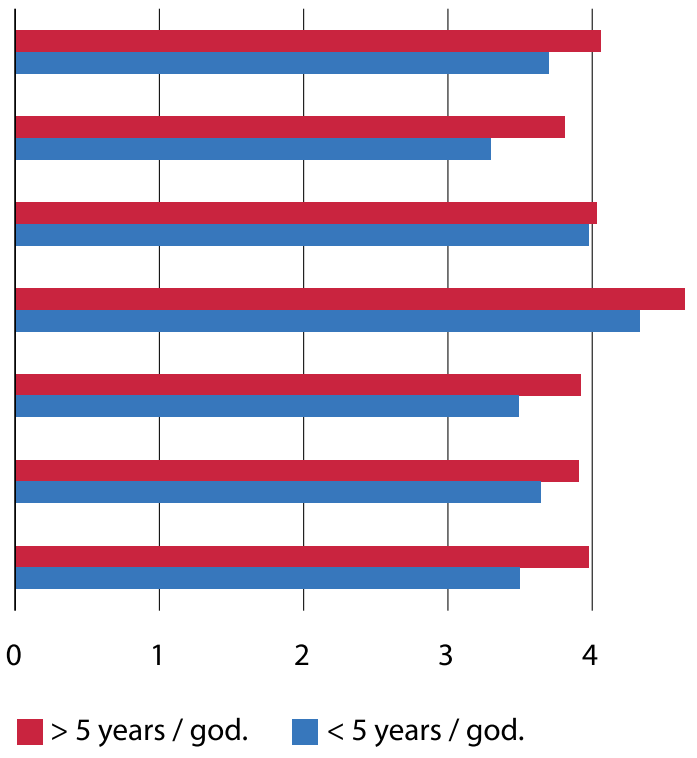

FIGURE 4. Satisfaction scores according to therapy (bDMARD vs. no bDMARD) SLIKA 4. Ocjene zadovoljstva ovisno o tome primaju li bolesnici biološku terapiju
FIgURE 5. Satisfaction scores according to disease duration

FIGURE 5. Satisfaction scores according to disease duration
0.63. A total of 29 patients were treated with biologic therapy (TNF- $\alpha$ inhibitors, tocilizumab, rituximab) at the time of completing the questionnaire.

The questions in the Satisfaction Questionnaire were divided into six categories: General Satisfaction (A), Patient Information (B), Empathy towards the Patient (C), Technical Quality and Competence (D), Attitude towards the Patient (E), Approach and Continuity of Medical Care (F), and a special category of average (total) level of satisfaction that combined all grades. The average satisfaction ratings in the above categories were as follows: A - 3.914; $\mathrm{B}-3.875$; C -3.877 ; D 4.599; E - 4.034; F - 3.754; and a total score of 4.007.

The obtained results showed that patients are largely satisfied with the service provided. The highest scores were achieved in the categories of technical quality and competence of the doctor (D) and attitude of the doctor towards the patient (E) (Figure 1). jenata u trenutku ispunjavanja upitnika liječeno biološkom terapijom (inhibitori TNF- $\alpha$, tocilizumab, rituksimab).

Pri analizi su pitanja iz Upitnika o zadovoljstvu podijeljena u šest kategorija: Općenito zadovoljstvo (A), Informiranost bolesnika (B), Empatija prema bolesniku (C), Tehnička kvaliteta i kompetentnost (D), Odnos prema bolesniku (E), Pristup i kontinuitet skrbi (F) te posebna kategorija Prosječne (ukupne) razine zadovoljstva koja ujedinjuje sve ocjene. Srednje ocjene zadovoljstva u navedenim kategorijama bile su redom: A - 3,914; B - 3,875; C - 3,877; D - 4,599; E - 4,034; F 3,754; uz ukupnu ocjenu 4,007.

Dobiveni su rezultati pokazali da su bolesnici uvelike zadovoljni pruženom uslugom. Najviše ocjene postignute su u kategorijama tehničke kvalitete i kompetentnosti liječnika (D) te odnosa liječnika prema bolesniku (E) (slika 1.). 
The highest ratings of satisfaction were recorded in the patients' feeling that they are in good hands when they come to the clinic, the competence of the doctor, the level of medical care provided in the clinic, thoroughness in the doctor's approach, and the patients' trust in the doctor. The lowest satisfaction ratings were related to the impossibility of easy telephone access, or additional consultation if necessary, and to the length of waiting in the waiting room.

The level of disease activity measured according to the DAS28-SE score did not significantly affect the degree of patient satisfaction with the service provided (Figure 2). In the average satisfaction level, the mean score in the group with DAS28 $<2.6$ (remission) was $4.06 \pm 0.44$, and in the group with DAS28 $>2.6$ (active disease) it was $3.98 \pm 0.39$ (T-test of independent samples, $t=0.62, p=0.534)$. In contrast, patients enrolled in the severe-to-very severe disability group according to the HAQ questionnaire reported a slightly lower level of satisfaction in all study categories, although the difference between the groups did not reach significance (Figure 3). For example, in the category of average satisfaction level (ANOVA test), in the group with HAQ 0-1 (21 subjects) the mean value was $4.01 \pm 0.47$, in the group with HAQ 1-2 (26 subjects) it was $4.05 \pm$ 0.35 , and in the group with HAQ 2-3 (6 subjects) it amounted to $3.80 \pm 0.37(\mathrm{p}=0.402)$.

In the group of patients treated with biological therapy (29 subjects), a significantly higher satisfaction score was recorded in the category Approach and Continuity of Care $(\mathrm{F})(\mathrm{p}=0.02)$ (Figure 4).

Patients diagnosed with RA more than 5 years before $(\mathrm{n}=47)$ showed a higher degree of satisfaction in the categories Empathy towards the Patient $(\mathrm{C})(\mathrm{p}=$ $0.02)$ and Average Satisfaction in all Categories (AF) $(\mathrm{p}=0.05)($ Figure 5).

\section{DISCUSSION}

The presented results show relatively high ratings of satisfaction in all observed categories, which indicates that there is a good relationship between patients and the physician (rheumatologist), regardless of the chronic nature of the disease. Satisfaction ratings also signify the benefits of an individual approach to the patient, i.e., the fact that each patient has their own rheumatologist, which was not the case in the original study, in which this was the main source of dissatisfaction (9). The highest scores were recorded in the domain of doctor-patient relationship and patient trust in physician, and the lowest scores were awarded for accessibility and information providing (according to treatment side effects and course of the disease). Although no statistical significance was achieved, there was a tendency towards lower scores in the group of severe-to-very severe disability (HAQ values between
Najviše ocjene zadovoljstva zabilježene su u osjećaju bolesnika da su u dobrim rukama kada dođu u ambulantu, kompetentnosti liječnika, razini skrbi pružene u ambulanti, temeljitosti u pristupu liječnika te povjerenju bolesnika prema liječniku. Najniže ocjene zadovoljstva odnosile su se na nemogućnost jednostavnoga telefonskog pristupa ili izvanredne konzultacije ako je potrebna te na duljinu čekanja u čekaonici.

Razina aktivnosti bolesti mjerena prema DAS 28-SE nije bitno utjecala na stupanj zadovoljstva bolesnika pruženom uslugom (slika 2.). U kategoriji prosječne razine zadovoljstva srednja vrijednost ocjene u skupini bolesnika s DAS $28<2,6$ (remisija) bila je 4,06 $\pm 0,44$, a u skupini s DAS $28>2,6$ (aktivna bolest) 3,98 $\pm 0,39$ (T-test nezavisnih uzoraka, $\mathrm{t}=0,62, \mathrm{p}=0,534$ ). Nasuprot tomu, bolesnici koji su prema HAQ-u ubrojeni u skupinu teške do vrlo teške onesposobljenosti javili su nešto niži stupanj zadovoljstva u svim ispitivanim kategorijama, premda razlika među grupama nije dosegnula značajnost (slika 3.). Na primjeru kategorije prosječne razine zadovoljstva (test ANOVA), u skupini s HAQ $0-1$ (21 ispitanik) srednja vrijednost ocjene bila je 4,01 $\pm 0,47$, u skupini s HAQ 1 - 2 (26-ero ispitanika) 4,05 $\pm 0,35$, a u skupini s HAQ 2 - 3 (6-ero ispitanika) 3,80 $\pm 0,37(\mathrm{p}=0,402)$.

U skupini bolesnika liječenih biološkom terapijom (29-ero ispitanika) znatnije viša ocjena zadovoljstva zabilježena je u kategoriji Pristup i kontinuitet skrbi (F) $(\mathrm{p}=0,02)$ (slika 4.).

Bolesnici u kojih je RA dijagnosticiran prije više od 5 godina $(\mathrm{n}=47)$ pokazali su viši stupanj zadovoljstva u kategorijama Empatija prema bolesniku $(\mathrm{C})(\mathrm{p}=$ $0,02)$ i Prosječno zadovoljstvo u svim kategorijama (A - F) $(\mathrm{p}=0,05)($ slika 5.).

\section{RASPRAVA}

Iz iznesenih rezultata mogu se iščitati relativno visoke ocjene zadovoljstva u svim promatranim kategorijama, što upućuje na to da postoji dobar odnos bolesnika s ordinirajućim liječnikom (reumatologom) bez obzira na kroničan karakter bolesti. Ocjene zadovoljstva govore i u prilog dobrobiti individualnog pristupa bolesniku, tj. tomu što svaki bolesnik ima svojeg reumatologa, a toga nije bilo u prvotnoj studiji, što je ujedno bio i glavni izvor nezadovoljstva (9). Najviše ocjene zabilježene su u domeni odnosa liječnik - bolesnik i povjerenja bolesnika u liječnika, a najniže ocjene dodijeljene su za pristupačnost i pružanje informacija (o nuspojavama liječenja i tijeku bolesti). Iako nije dosegnuta statistička značajnost, opaža se tendencija prema nižim ocjenama u skupini teške do vrlo teške onesposobljenosti (vrijednost HAQ-a između 2 i 3). Nadalje, prema rezultatima našeg istraživanja, aktivnost bolesti ne utječe na percepciju kvalitete skrbi. Suprotno tomu, dugotrajna je bolest ( $>5$ godina) po- 
2 and 3). Furthermore, according to the results of our study, disease activity does not affect the perception of care quality. In contrast, long-term illness ( $>5$ years) is associated with greater satisfaction with the service provided in terms of stronger physician empathy for the patient and greater general patient satisfaction. Also, patients treated with biologic therapy are more satisfied with the possibility of easier health care access in the rheumatology clinic. This probably results from the regular visits to the day hospital during which a routine medical examination is performed before therapy, or the communication with medical staff who provide subcutaneous biologics. Lower grades in individual categories, as well as individual issues, provide insight into the components of care in outpatient work that must be improved (possibility of easy access or additional consultation, length of waiting in the waiting room).

According to a cross-sectional study by Jacobi et al. on the satisfaction of patients with RA who are in the routine care of a rheumatologist, no strong proof has been found that the patient characteristics (e.g., health, social, demographic) are associated with quality assessment (10). In contrast, other studies shown that patients' assessments of health-care quality may be influenced by sociodemographic (age, education, marital status) $(11,12)$ and health characteristics $(11,13-16)$. The level of functional disability could affect grades, as shown in some of the studies $(11,13-16)$. Older patients and women assign slightly better scores than younger patients and men (10). Inadequate quality scores were marked in the domain of drug information, symptom information, and information in understandable language (10), which is in accordance with the lower scores in related categories in our study.

It is known that only a small proportion of patients talk to their physician about pain, physical function, fatigue, and health-related quality of life (HR-QoL) (17).

Other studies also showed that daily pain, despite the new therapeutic options available, continues to be a major ailment for patients, and being free of pain and fatigue is a major indicator of a 'good day'. The responses obtained from the questionnaires clearly emphasize the deeper, hidden effect of the disease, suggesting a loss of self-confidence, feelings of separation and isolation, and stress that negatively affects the patients' emotional well-being and relationships with family, friends, and partners $(18,19)$. From the patient perspective, a targeted, effective approach to treatment involves setting personal, social, and therapeutic goals as well as monitoring disease progression to achieve those goals.

This is accordant with other studies, in which communication between physician and patient focuses on symptoms or treatment options rather than on health- vezana $s$ većim zadovoljstvom pruženom uslugom $s$ obzirom na snažnije empatije liječnika prema bolesniku te većim općenitim zadovoljstvom bolesnika. Također, bolesnici liječeni biološkom terapijom zadovoljniji su mogućnošću lakšeg pristupa zdravstvenoj skrbi u reumatološkoj poliklinici koja vjerojatno proizlazi iz redovitih posjeta dnevnoj bolnici tijekom kojih se provodi redoviti liječnički pregled prije aplikacije terapije ili iz komunikacije s osobljem poliklinike pri preuzimanju supkutanog oblika bioloških lijekova. Niže ocjene u pojedinim kategorijama, kao i pojedinačna pitanja daju uvid u komponente skrbi u polikliničkom radu koje je potrebno poboljšati (mogućnost jednostavnijeg pristupa ili izvanredne konzultacije, duljina čekanja u čekaonici).

Prema presječnom istraživanju Catharine Jacobi i suradnika o zadovoljstvu pacijenata s RA koji su u skrbi reumatologa, nije nađen čvrst dokaz da su karakteristike pacijenata (zdravstvene, sociodemografske) povezane s ocjenama kvalitete (10). Suprotno tomu, u drugim provedenim istraživanjima dokazano je da ocjene pacijenata o kvaliteti skrbi mogu biti pod utjecajem sociodemografskih karakteristika (dob, edukacija, bračni status) $(11,12)$ i zdravstvenih karakteristika $(11,13$ - 16). Razina funkcionalne onesposobljenosti mogla bi utjecati na ocjene, što i jest prikazano u nekim od istraživanja $(11,13-16)$. Stariji pacijenti i žene dodjeljuju nešto bolje ocjene nego mlađi bolesnici i muškarci (10). Neadekvatne ocjene kvalitete zabilježene su u područjima informacije o lijekovima, informacije o tijeku simptoma i informacije razumljivim jezikom (10), što je u skladu s nižim ocjenama u srodnim kategorijama u našem istraživanju.

Poznato je da tek manji udio bolesnika razgovara sa svojim liječnikom o boli, fizičkoj funkciji, umoru, kvaliteti života povezanoj sa zdravljem (HRQoL) (17).

Također, iz drugih je istraživanja razvidno da dnevna bol, unatoč dostupnosti novih terapijskih opcija, nastavlja biti glavna tegoba bolesnika, a biti bez boli i umora glavni je indikator 'dobrog dana'. Odgovori dobiveni iz provedenih upitnika jasno naglašavaju dublji, skriveni efekt bolesti upućujući na gubitak samopouzdanja, osjećaje odvojenosti i izoliranosti te stres koji negativno utječe na emocionalno blagostanje pacijenata i odnose s obitelji, prijateljima i partnerima $(18,19)$. Iz perspektive pacijenata ciljani, učinkovit pristup liječenju sastoji se od postavljanja osobnih, socijalnih i terapijskih ciljeva, kao i nadziranja progresije bolesti kako bi se navedeni ciljevi postigli. To je u skladu s drugim studijama, u kojima se komunikacija između liječnika i bolesnika više usredotočuje na simptome ili opcije liječenja nego na kvalitetu života povezanu sa zdravljem (HRQoL) (20). Zamijećeno je da bolesnici i liječnici uzimaju u obzir različite aspekte RA kada se donose odluke o terapiji $(21-23)$. Mnogi bolesnici 
related quality of life (HRQL) (20). It has been observed that patients and physicians consider different aspects of RA when making treatment decisions (2123). Many patients are unable to adequately express the burden of the disease they are feeling or expectations they have of a particular therapeutic approach. Therefore, the physician should initiate a more detailed discussion of expectations with the patient and strive to explain the treat-to-target approach in RA treatment $(18,24)$. The most important limitation of this study is the small number of respondents.

In conclusion, in this study conducted at a single institution, regardless of the chronic character of RA a satisfactory relationship was found between the patient and the competent rheumatologist, which is partly due to the individual approach to patients. Patients with a higher level of functional disability expressed a slightly lower level of satisfaction with the care provided in the rheumatology clinic, while patients with long-term illness as well as those treated with biologic therapy showed higher satisfaction with the specialist service provided. Inadequate quality assessments in the area of providing information on the course of the disease and prescribed therapy, the availability of physicians, and long waiting times are among the items of care that need to be improved. Finally, research indicates that an important approach in the treatment of RA patients is to set individual goals, which include a psychosocial component, as well as regular monitoring of the course of the disease.

Conflict of interest statement: Authors declare no conflict of interest.

\section{REFERENCES / LITERATURA}

1. Smolen JS, Landewé R, Bijlsma J, Burmester G, Chatzidionysiou K, Dougados M i sur. EULAR recommendations for the management of rheumatoid arthritis with synthetic and biological disease-modifying antirheumatic drugs: 2016 update. Ann Rheum Dis. 2017;76(6):960-77.

2. Smolen JS, Sokka T, Pincus T, Breedveld FC. A proposed treatment algorithm for rheumatoid arthritis: aggressive therapy, methotrexate, and quantitative measures. Clin Exp Rheumatol. 2003;21(5 Supl 31):S209-10.

3. Wolfe F, Cathey MA, Kleinheksel SM. Fibrositis (Fibromyalgia) in rheumatoid arthritis. J Rheumatol. 1984;11(6):814-8.

4. Leeb BF, Andel I, Sautner J, Nothnagl T, Rintelen B. The DAS28 in rheumatoid arthritis and fibromyalgia patients. Rheumatology (Oxford). 2004;43(12):1504-7.

5. Leeb BF, Andel I, Leder S, Leeb BA, Rintelen B. The patient's perspective and rheumatoid arthritis disease activity indexes. Rheumatology (Oxford). 2005;44(3):360-5. nisu u stanju prikladno iskazati teret bolesti koji osjećaju ni očekivanja koja imaju od određenoga terapijskog pristupa. Stoga bi liječnik trebao s bolesnikom inicirati detaljniju raspravu o očekivanjima i truditi se objasniti pristup treat-to-target liječenju RA $(18,24)$. Najvažnije ograničenje ovog ispitivanja bio je malen broj ispitanika.

Zaključno, bez obzira na kroničan karakter RA, u ovom je istraživanju, provedenom u jednoj ustanovi, nađen zadovoljavajući odnos između bolesnika i mjerodavnog reumatologa, što je dijelom zasigurno i zbog individualnog pristupa pacijentima. Pacijenti s višom razinom funkcionalne onesposobljenosti izrazili su nešto nižu razinu zadovoljstva pruženom skrbi u reumatološkoj poliklinici, dok su pacijenti s dugotrajnom bolesti, kao i oni liječeni biološkom terapijom bili zadovoljniji pruženom specijalističkom uslugom. Neadekvatne ocjene kvalitete u područjima pružanja informacija o tijeku bolesti i ordiniranoj terapiji, dostupnosti liječnika i dugog čekanja stavke su skrbi koje je potrebno poboljšati. Konačno, istraživanje upućuje na to da važan pristup pri liječenju bolesnika $s$ RA čine postavljanje individualnih ciljeva, koji uključuju i psihosocijalnu komponentu, kao i redovito praćenje tijeka bolesti.

IZJAVA o SUKobu interesa: Autori izjavljuju da nisu u sukobu interesa.

Translated on English/Prijevod na engleski Lorena Petrač

6. Her M, Kavanaugh A. Patient-reported outcomes in rheumatoid arthritis. Curr Opin Rheumatol. 2012;24(3):327-34.

7. Ward V, Hill J, Hale C, Bird H, Quinn H, Thorpe R. Patient priorities of care in rheumatology outpatient clinics: a qualitative study. Musculoskeletal Care. 2007;5(4):216-28.

8. Taylor P, Manger B, Alvaro-Gracia J, Johnstone R, Gomez-Reino J, Eberhardt E i sur. Patient perceptions concerning pain management in the treatment of rheumatoid arthritis. J Int Med Res. 2010;38(4):1213-24.

9. Hill J, Bird HA, Hopkins R, Lawton C, Wright V. Survey of satisfaction with care in a rheumatology outpatient clinic. Ann Rheum Dis. 1992;51(2):195-7.

10. Jacobi CE, Boshuizen HC, Rupp I, Dinant HJ, van den Bos GAM. Quality of rheumatoid arthritis care: the patient's perspective. Int J Qual Health Care. 2004;16(1):73-81.

11. Lewis JR. Patient views on quality care in general practice: literature review. Soc Sci Med. 1994;39(5):655-70. 
12. Hall JA, Dornan MC. Patient sociodemographic characteristics as predictors of satisfaction with medical care: a meta-analysis. Soc Sci Med. 1990;30(7):811-8.

13. Bendtsen P, Bjurulf P. Perceived needs and patient satisfaction in relation to care provided in individuals with rheumatoid arthritis. Qual Assur Health Care. 1993;5(3):243-53.

14. Williams B. Patient satisfaction: a valid concept? Soc Sci Med. 1994;38(4):509-16.

15. Donabedian A. The quality of care. How can it be assessed? JAMA. 1988;260(12):1743-8.

16. Hall JA, Dornan MC. Meta-analysis of satisfaction with medical care: description of research domain and analysis of overall satisfaction levels. Soc Sci Med. 1988;27(6):637-44.

17. McInnes IB, Combe B, Burmester G. Understanding the patient perspective - results of the Rheumatoid Arthritis: Insights, Strategies \& Expectations (RAISE) patient needs survey. Clin Exp Rheumatol. 2013;31(3):350-7.

18. Strand V, Wright GC, Bergman MJ, Tambiah J, Taylor PC. Patient Expectations and Perceptions of Goal-setting Strategies for Disease Management in Rheumatoid Arthritis. J Rheumatol. 2015;42(11):2046-54.

19. Radawski C, Genovese MC, Hauber B, Nowell WB, Hollis K, Gaich CL i sur. Patient Perceptions of Unmet Medical Need in
Rheumatoid Arthritis: A Cross-Sectional Survey in the USA. Rheumatol Ther. 2019;6(3):461-71.

20. Kvrgic Z, Asiedu GB, Crowson CS, Ridgeway JL, Davis JM. "Like No One Is Listening to Me": A Qualitative Study of Patient-Provider Discordance Between Global Assessments of Disease Activity in Rheumatoid Arthritis. Arthritis Care Res. 2018;70(10):1439-47.

21. Robinson SM, Walker DJ. Negotiating targets with patients: choice of target in relation to occupational state. Rheumatology (Oxford). 2012;51(2):293-6.

22. van Hulst LTC, Kievit W, van Bommel R, van Riel PLCM, Fraenkel L. Rheumatoid arthritis patients and rheumatologists approach the decision to escalate care differently: results of a maximum difference scaling experiment. Arthritis Care Res. 2011;63(10):1407-14.

23. Otter SJ, Lucas K, Springett K, Moore A, Davies K, Young A i sur. Identifying patient-reported outcomes in rheumatoid arthritis: the impact of foot symptoms on self-perceived quality of life. Musculoskeletal Care. 2012;10(2):65-75.

24. Gibofsky A, Galloway J, Kekow J, Zerbini C, de la Vega M, Lee $\mathrm{G}$ i sur. Comparison of patient and physician perspectives in the management of rheumatoid arthritis: results from global physician- and patient-based surveys. Health Qual Life Outcomes. 2018;16(1):211.

\section{LIST OF REVIEWERS for articles in volume 65 and $66(2018 / 2019)$ / POPIS RECENZENATA za članke u volumenu 65 i 66 (2018./2019.)}

\section{Recenzenti - 2018. godina}

dr. sc. Felina Anić, dr. med. prim. dr. sc. Alen Bišćanin, dr. med. dr. sc. Mislav Cerovec, dr. med. mr. sc. Ružica Čunović Dubroja, dr. med. Ines Doko, dr. med. dr. sc. Ana Gudelj Gračanin, dr. med. dr. sc. Joško Mitrović, dr. med. prof. dr. sc. Srđan Novak, dr. med. doc. dr. sc. Diana Perković, dr. med. prim. dr. Mirna Sentić, dr. med. dr. sc. Lea Šalamon, dr. med. doc. dr. sc. Darija Vranešić Bender

\author{
Recenzenti - 2019. godina \\ Marko Barešić, dr. med. \\ Katarina Borić, dr. med. \\ Ivana-Melanie Čulo, dr. med. \\ dr. sc. Ines Doko Vajdić, dr. med. \\ doc.dr.sc. Vlasta Đuranović, dr. med. \\ dr. sc. Emina Ejubović, dr. med. \\ prof. dr. sc. Simeon Grazio, dr. med. \\ dr. sc. Marina Ikić Matijašević, dr. med. \\ Katarina Kličan-Jaić, dr. med. \\ prof. dr. sc. Maša Malenica, dr. med. \\ prof. dr. sc. Srđan Novak, dr. med. \\ Silva Pukšić, dr. med. \\ doc. dr. sc. Višnja Prus, dr. med. \\ Hana Skala Kavanagh, dr. med. \\ Ljiljana Smiljanić Tomičević, dr. med. \\ dr. sc. Lea Šalamon, dr. med. \\ Tatjana Zekić, dr. med.
}

The editorial board thanks colleagues for the reviews, which raised the quality of the magazine. / Urednički odbor zahvaljuje kolegama na recenzijama, čime su podigli kvalitetu časopisa. 